\title{
Use of platelet-rich plasma in orthopaedics and traumatology
}

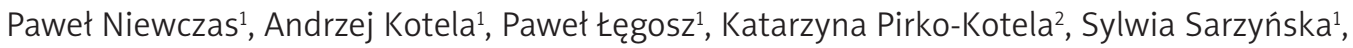 \\ Małgorzata Starczyńska ${ }^{3}$ \\ 'Department of Orthopaedics and Traumatology of Musculoskeletal System, $1^{\text {st }}$ Faculty of Medicine, Medical University of Warsaw, \\ Warsaw, Poland \\ Head of the Department: Prof. Paweł Małdyk MD, PhD \\ 2Department of Internal Medicine and Endocrinology, $1^{\text {st }}$ Faculty of Medicine, Medical University of Warsaw, Warsaw, Poland \\ Head of the Department: Prof. Tomasz Bednarczuk MD, PhD \\ ${ }^{3}$ Department of Manual Therapy, Institute of Physiotherapy, Faculty of Medicine and Health Science, Jan Kochanowski University, \\ Kielce, Poland \\ Head of the Department: Zbigniew Śliwiński MD, PhD, Prof. JKU
}

Key words: traumatology, platelet rich plasma, orthopaedics.

Słowa kluczowe: traumatologia, osocze bogatopłytkowe, ortopedia.

\begin{abstract}
Platelet rich plasma (PRP) is a concentration of blood platelets suspended in a small volume of plasma, and it can be obtained by centrifuging the patient's whole blood. It is used in many fields of medicine, including orthopaedics and traumatology. The range of indications for PRP therapy has been extended. The mechanism of action of PRP is based on function of growth factors. The application of PRP can be considered for tendinopathy and enthesopathy treatment, osteoarthritis treatment, muscle and ligament injuries, bone lesion treatment, bone infections and many other diseases. There are no standardised guidelines concerning PRP therapy, and the most efficient and optimal method of PRP preparation is yet to be determined. This article aims to present the opportunities of PRP therapy in orthopaedics and traumatology and evaluate its effectiveness.
\end{abstract}

\section{Streszczenie}

Osocze bogatopłytkowe (PRP) to koncentrat płytek krwi w niewielkiej ilości osocza. Uzyskiwane jest ono z krwi pełnej pacjenta przez jej odwirowanie. Stosowane jest w wielu gałęziach medycyny, m.in. ortopedii i traumatologii narządu ruchu. Zakres wskazań do stosowania terapii osoczem bogatopłytkowym ciągle się rozszerza. Mechanizm działania osocza bogatopłytkowego opiera się na działaniu płytkowych czynników wzrostu. Leczenie osoczem bogatopłytkowym może być zastosowane $\mathrm{w}$ tendinopatiach i entezopatiach, chorobie zwyrodnieniowej stawów, w leczeniu urazów mięśni i więzadeł, w uszkodzeniach kości, w zakażeniach narzadu ruchu oraz wielu innych jednostkach chorobowych. Nie udało się dotąd stworzyć wystandaryzowanych zaleceń dotyczących stosowania osocza bogatopłytkowego. Brakuje również najkorzystniejszej i najbardziej optymalnej metody pozyskiwania koncentratu krwinek płytkowych. Celem artykułu jest zaprezentowanie możliwości terapii osoczem bogatopłytkowym w ortopedii i traumatologii narządu ruchu.

\section{Introduction}

Platelet-rich plasma (PRP) is a concentration of blood platelets suspended in a small volume of plasma. The first author who tried to define platelet-rich plasma was Marx [1], who suggested the concentration of 1 million platelets in $1 \mu$ of plasma (i.e. a level 4-5fold higher than that found in the peripheral blood). However, Anitua et al. [2] wrote about a platelet count of 300,000 in $1 \mu \mathrm{l}$ of plasma, which he named plasma rich in growth factors (PRGF). The definition of platelet-rich plasma remains controversial.

The first information about the use of platelet-rich plasma during cardiac surgery was published in 1987 by Ferrari et al. [3]. Since then, a number of clinical studies have been conducted and the range of indications has been constantly extending. In 1998, Marx et al. [4] presented study results concerning the use of PRP in mandibular continuity reconstruction, which showed higher bone density after the application of platelet-rich gel. At present, platelet-rich plasma is used in such medical fields as maxillofacial surgery, cardiac surgery, orthopaedics, sports medicine, dentistry [5, 6], aesthetic medicine [7] and general surgery [8].

Platelet-rich plasma is obtained by centrifuging the patient's whole blood [9]. As a result, blood cell counts are divided into three fractions: platelet-poor 
plasma, platelet-rich plasma (sometimes referred to as the buffy coat) and red blood cells. The next step is to separate the red blood cells from platelet-poor plasma and the buffy coat fractions. The other fractions are centrifuged using various speeds and times of spin. Platelets are isolated in a small volume of plasma. There are several industrial methods of obtaining PRP from the patient's blood which differ in terms of centrifugation parameters, type of blood containers or the anticoagulants used. Numerous studies have been conducted, but the best method of PRP preparation is yet to be determined [9].

The essence of platelet-rich plasma therapy consists in growth factors (GF). Three types of granules can be distinguished in the structure of platelets. The granules contain different substances [2]. Platelet $\alpha$-granules are comprised of haemostatic factors and regulators of inflammatory processes and wound healing. Substances stored in dense granules are thrombocyte-activating factors. Platelets also contain lysosomal granules, which secrete acid hydrolases. Platelet activation results in growth factor release. Platelet growth factors include platelet-derived growth factor (PDGF), transforming growth factor $\beta$ (TGF- $\beta$ ), vascular endothelial growth factor (VEGF), epidermal growth factor (EGF) and insulin-like growth factor 1 (IGF-1) [10]. The functions of these growth factors are presented in Table $1[10,11]$. It should be noted that the mechanism of action of platelet-rich plasma does not differ from the physiological healing process, but allows for obtaining higher concentrations of growth factors. As a result, the process of tissue regeneration is accelerated.

Recently, platelet-rich plasma therapy has been gaining in popularity. The number of reports concerning the effectiveness of PRP therapy is growing. These trials are mainly based on small groups of patients; case reports are also presented. However, there is still a dearth of randomised clinical trials with large groups of patients, even though this is the basis of evidence-based medicine (EBM). Meta-analyses of the data are also hindered due to the lack of standardisation of PRP preparation, the use of additional therapies (rehabilitation, drug therapy), differences in the anatomical structures examined and various methods of treatment efficacy assessment. Consequently, guidelines of PRP preparation should be developed and indications for its use should be established.

This paper presents a review of the literature concerning the use of platelet-rich plasma in orthopaedics and traumatology.

\section{Use of platelet-rich plasma in enthesopathy and tendinopathy treatment}

Tendon and enthesis disorders constitute a widespread problem commonly encountered by doctors. The disorders arise as a result of accumulating microinjuries caused by flexing of muscles and ligaments. Overload of these structures also leads to chronic osteoarthritis. In the first phase of the disease, elimination of the overload allows for effective tissue regeneration. Further overload leads to the degeneration and impairment of tissue repair mechanisms, resulting in chronic degenerative tendinopathy. Conservative treatment includes limb elevation, eccentric training or topical administration of steroids, but the effectiveness of these methods is negligible. Consequently, specialists search for new methods of treatment of tendinopathy and enthesopathy. Platelet-rich plasma therapy is one of these methods.

The use of platelet-rich plasma therapy has been gaining in popularity, and the number of reports concerning the effectiveness of PRP in the treatment of enthesopathy and tendinopathy has been increasing. The therapy is applied mainly in patients who do not

Table 1. Platelet growth factors and their functions [10, 11]

\begin{tabular}{|c|c|c|}
\hline Growth factor & Abbreviation & Functions \\
\hline $\begin{array}{l}\text { Transforming growth } \\
\text { factor }\end{array}$ & TGF- $\beta$ & $\begin{array}{l}\text { A mitogen for fibroblasts, smooth muscle cells, osteoblasts } \\
\text { Angiogenesis promotion, extracellular matrix production }\end{array}$ \\
\hline $\begin{array}{l}\text { Platelet-derived growth } \\
\text { factor }\end{array}$ & PDGF & $\begin{array}{l}\text { Chemotactic effect on monocytes, neutrophils, fibroblasts, mesenchymal } \\
\text { stem cells and osteoblasts } \\
\text { A mitogen for fibroblasts and smooth muscle cells } \\
\text { Angiogenesis promotion, formation of fibrous tissue, re-epithelialisation }\end{array}$ \\
\hline $\begin{array}{l}\text { Vascular endothelial } \\
\text { growth factor }\end{array}$ & VEGF & $\begin{array}{l}\text { Angiogenesis promotion } \\
\text { Chronic wound healing promotion } \\
\text { Inhibition of bone formation }\end{array}$ \\
\hline Epidermal growth factor & EGF & $\begin{array}{c}\text { A mitogen for fibroblasts, endothelial cells, keratinocytes } \\
\text { Chronic wound healing promotion }\end{array}$ \\
\hline $\begin{array}{l}\text { Insulin-like growth } \\
\text { factor }\end{array}$ & IGF-1 & $\begin{array}{l}\text { Regulation of bone maintenance } \\
\text { Modulator of cell apoptosis } \\
\text { Stimulation of bone tissue regeneration }\end{array}$ \\
\hline
\end{tabular}


respond to conservative treatment in order to avoid surgery and shorten the convalescence period.

Gautam et al. [12] compared the results of PRP and corticosteroid (CS) injections in the treatment of lateral epicondylitis (LE) in a randomised trial. A total of 30 patients were randomised to receive PRP or corticosteroid injections. The patients were assessed using a visual analogue scale (VAS) for pain, the Disabilities of the Arm, Shoulder and Hand (DASH) score, the Oxford Elbow Score, the modified Mayo Clinic performance index for the elbow (modified Mayo score) and hand grip strength. Ultrasound scans were performed to evaluate the tear at the common extensor origin, oedema at the common extensor origin, cortical erosion and thickness of the tendon. During a 6-month follow-up, the scores improved significantly in both the PRP and CS group. However, in the CS group, the scores peaked at 3 months and then decreased, indicating recurrence of symptoms in $46.7 \%$ of the CS patients. Another study carried out by Behera et al. [13] was a comparison of PRP injections versus bupivacaine injections for recalcitrant lateral epicondylar tendinopathy. The trial enrolled 25 patients whose condition was assessed with a VAS for pain, the modified Mayo clinic performance index for elbow (MMCPIE) and the Nirschl score for activity-related pain at 1, 3, 6 and 12 months. The study showed that after 1 month, the percentage of improvement was lower in the PRP than the bupivacaine group $(17.7 \%$ vs. $26.5 \%$ in VAS for pain, $24 \%$ vs. $27.6 \%$ in MMCPIE score and $20.7 \%$ vs. $31.1 \%$ in Nirschl score). Different results showing better outcomes of PRP injections were achieved after 3, 6 and 12 months.

Kearney et al. [14] conducted a study which evaluated the differences between patients with Achilles tendinopathy treated with a PRP injection compared with an eccentric loading programme. A total of 20 patients were randomised to receive a PRP injection or an eccentric loading programme. The outcomes were measured with the Victorian Institute of Sport Assessment - Achilles questionnaire (VISA-A) at baseline, 6 weeks, 3 months and 6 months. The mean VISA-A score for the injection group was 76.0 (range: 58.3-93.7), and in the exercise group the value was 57.4 (range: $38.1-76.7$ ). However, the authors point out that the outcome of this study is questionable as the study group was too small; consequently, the study should be repeated with a larger group of patients. The effectiveness of PRP in the treatment of Achilles tendinopathy was also presented in a clinical study carried out by de Vos et al. [15]. The tendon structure was evaluated by ultrasonographic tissue characterisation and colour Doppler ultrasound was used to measure the degree of neovascularisation. A significant improvement was found after 24 weeks both in the PRP group and the placebo group, but the between-group difference was not significant. It was concluded that injecting PRP in the treatment of chronic Achilles tendinopathy does not contribute to an improved tendon structure or alter the degree of neovascularisation. The treatment failure was probably caused by the fact that PRP was present at the site of the lesion for a shorter time as the fluid might have diffused rapidly out of the tendon due to the internal hydrostatic pressure. These data should be verified by further research.

\section{Use of platelet-rich plasma in osteoarthritis treatment}

Osteoarthritis (OA) is one of the most frequent dysfunctions of the musculoskeletal system. Many biological and mechanical factors interrupt the physiological process of cartilage and subchondral bone regeneration and cause joint damage [16]. The disorder is characterised by pain in the affected joint and limited mobility [17]. Neither conservative (exercise and lifestyle modification) nor pharmacological treatment is effective. The use of platelet-rich plasma may be an alternative method of osteoarthritis treatment.

The availability of data confirming the effectiveness of PRP therapy in the treatment of osteoarthritis is increasing. The results concern mainly the knee. Patel et al. [18] compared the outcomes of PRP therapy for knee osteoarthritis with placebo. A total of 78 patients (156 knees) with bilateral OA were divided randomly into three groups. Group A (52 knees) received a single injection of PRP, group B (50 knees) received 2 injections of PRP and group C (46 knees) received a single injection of normal saline. The condition of the patients was evaluated with the Western Ontario and McMaster Universities Osteoarthritis Index (WOMAC) questionnaire and a VAS scale for pain at baseline, 6 weeks, 3 months and 6 months after treatment. In group A, a statistically significant improvement was found in all WOMAC parameters (average total score at baseline of $49.86 \mathrm{vs}$. average total score at 6 months after treatment of 27.18). Similar results were observed in group B (average total score at baseline of 53.20 vs. final follow-up at 6 months after treatment of 30.48). Group C did not show any improvement.

Platelet-rich plasma therapy has been compared with different methods of osteoarthritis treatment. Angoorani et al. [19] conducted a trial which collated the effect of PRP with transcutaneous electrical nerve stimulation (TENS) and exercise in the treatment of patients with knee osteoarthritis. Fifty-four patients with knee OA were randomly assigned to two groups: group A (27 patients) received 2 injections of PRP 4 weeks apart, and group B (27 patients) received 10 sessions of TENS and exercise. Clinical outcomes were evaluated with the Knee Injury and Osteoarthritis Outcome Score (KOOS) questionnaire and a VAS scale. The results were better in group A than in group B. Battaglia et al. [20] found long-term advantages of PRP and hyaluronic acid therapy for hip osteoarthri- 
tis; the outcomes were similar in both groups. However, it should be noted that a significant improvement was observed within 3 months after the treatment. Despite a slightly progressive decrease during further follow-up, the final clinical scores remained higher compared with baseline, with no significant differences between PRP and hyaluronic acid.

\section{Use of platelet-rich plasma in muscle and ligament injuries}

Approximately 30\% of injuries are associated with the muscular system, and muscle injuries are one of the most common types of sport-related trauma, causing $10-55 \%$ of all damage [21, 22]. Muscle injuries are becoming a global problem, and there is a need to invent new methods of tissue repair stimulation [23]. Platelet-rich plasma therapy is an example of a tissue repair method. Quarteiro et al. [24] evaluated the effect of PRP on the repair of muscle injuries in rats. The authors produced injuries in the gastrocnemius muscles of each hind limb of 30 rats. These injuries did not receive any treatment in 6 rats, while in 24 rats normal saline was injected into the injury site in the left leg and PRP was administered into the injury site in the right leg. Samples of the treated and untreated tissue were evaluated 7 and 21 days after the procedures. The quantity of collagen in the injury sites treated with PRP was significantly lower than that in the other injuries 7 days after the procedure. The collagen levels in both groups were equal on the $21^{\text {st }}$ day. There was a significant increase in the quantity of collagen between the $7^{\text {th }}$ and $21^{\text {st }}$ day in the injuries treated with PRP. The inflammatory process was shown to be more intense in the injuries treated with PRP than in the injuries of the other treatment groups. The authors concluded that PRP has little influence on the primary steps of muscle tissue healing.

Apart from a large number of animal studies, clinical study results have also been presented. Jose Martinez-Zapata et al. [25] conducted a multicentre, randomised, double-blind clinical trial in 71 patients with muscle tears in the legs and haematoma. The haematoma was evacuated in all patients. Thirty-three patients were randomised to a single dose of autologous PRP and the other 38 patients to simulated PRP administration. The primary end-point of the study was the time to complete recovery of the muscle. The secondary end-points were pain, relapses, ultrasound parameters and adverse events. The time from the introduction of the treatment to complete recovery was 31.63 days in the PRP group and 38.43 days in the control group. The authors concluded that the PRP therapy did not significantly improve the time necessary to heal as compared with the control group. Pain decreased over time in both groups without statistical differences between them. Similar conclusions were drawn by Reurink et al. [26]. They carried out a trial in 80 patients who received two injections of PRP or isotonic saline placebo. The study results did not show any differences in the median time to recovery between the groups. On the other hand, Hamid et al. [27] achieved recovery in the PRP group 2 weeks earlier than in the other group, which is a significant difference.

The use of PRP in the treatment of ligament damage is mainly focused on the anterior cruciate ligament (ACL). Dhillon et al. [28] evaluated the effect of human ACL cell growth of 11 patients during ACL reconstruction surgery. The ACL remnants were collected, and the cells were isolated, identified and cultured and then divided into six groups. Groups A-D had fetal bovine serum (FBS) added to them along with different concentrations of PRP and platelet-poor plasma (PPP). Groups E and F received 5\% and 10\% PRP, respectively, but lacked FBS. The study showed that the addition of PRP increased the viability of ACL cells in 4 out of 11 donor samples and promoted cell proliferation in 8 out of 11 samples. The difference between the effectiveness of 5\% and 10\% PRP was not statistically significant. However, there was no statistically significant effect of either PRP or PPP on the prevention of cell death (apoptosis rate).

In vitro trial results are not correlated with clinical practice. In a study conducted by Komzák et al. [29], 20 patients underwent ACL reconstruction surgery with PRP application to the bone tunnel for a graft and to the articular cavity, while another 20 subjects had the same surgery without PRP administration. The patients were examined by MRI at 3 and 12 months after surgery, and the knee functional status was evaluated with scoring systems (Cincinnati score, IKDC score). Three months after surgery, bone swelling was found in 18 out of 20 patients in both the PRP and the control group. At 12 months, bone swelling was recorded in 7 out of 20 patients in the PRP group and in 9 patients from the control group. The mean Cincinnati score at 3 months was 72.7 in the PRP group and 73.4 in the control group. The functional score after 12 months improved to 97.5 in the PRP group and to 95.1 in the control group. The IKDC scores at 3 and 12 months were also similar in both groups. The outcomes led to the conclusion that the use of PRP in ACL reconstruction does not accelerate graft remodelling and bone ingrowth into the tendon. Similar conclusions were presented by Silva et al. [30]. Patients after ACL reconstruction surgery were divided into the PRP and nonPRP group and evaluated with MRI 3 months after the procedure. There were no significant differences between the PRP and non-PRP group.

Different study results were presented by Radice et al. [31]. They found that with the use of PRP gel, complete homogeneity of the ACL graft was seen earlier (179 days) as compared with the non-PRP gel group (369 days). These conclusions should be analysed in further studies comparing PRP therapy with PRP gel therapy in facilitating ligament injury healing. 


\section{Use of platelet-rich plasma in bone lesion treatment}

The regenerative ability of bone is relatively efficient. Bone injuries are healed by bone union. This process is initiated by inflammation resulting from haematoma at the site of injury. Normal bone union requires meeting the criteria of the so-called Lynch triad. The Lynch triad consists of the following: a processable tissue matrix, live cells responsible for bone regeneration and signal particles of the healing process, which modulate the activity of inflammatory cells. The signal particles include growth factors, and platelet-rich plasma is a rich source of these molecules. The idea of using PRP in bone lesion treatment is based on the hypothesis that the administration of growth factors at the site of injury may initiate the regeneration process. Consequently, the number of clinical trials evaluating the use of PRP in the treatment of delayed long bone union is increasing.

The effectiveness of PRP therapy in the treatment of delayed bone union was assessed by Gołos et al. [32]. Their analysis encompassed 132 patients diagnosed with delayed bone union and treated with PRP. Bone union after PRP administration was found in 108 (81.8\%) patients. The treatment was most effective in patients with delayed union of the proximal tibia, and the lowest efficacy was observed in subjects with delayed union of the proximal humeral bone. These study results confirmed the effectiveness of PRP therapy in the treatment of delayed union of long bones. Similar outcomes were described by Stanton [33], who achieved bone union in $90 \%$ of patients. Unlike these authors, Say et al. [34] did not achieve satisfactory outcomes (the efficacy was only $30 \%$ ). Due to the contradictory study results, more trials should be conducted to confirm or refute the effectiveness of the therapy.

\section{Antibacterial effect of platelet-rich plasma therapy}

Bone lesion treatment is often complicated by bone infection. PRP gel therapy is also useful in this situation. Bielecki et al. [35] analysed the antibacterial effect of platelet-rich gel in vitro by using platelet-rich plasma samples from 20 volunteers. Susceptibility to platelet-rich gel was determined by the disc diffusion method. Antimicrobial activity was assessed by measuring the zones of inhibition. Platelet-rich gel inhibited the growth of Staphylococcus aureus and Escherichia coli. There was no activity against Klebsiella pneumoniae, Enterococcus faecalis or Pseudomonas aeruginosa. In addition, platelet-rich gel seemed to stimulate the in vitro growth of $P$. aeruginosa.

Promising study outcomes were described by Szypuła et al. [36]. They presented 4 case studies of patients suffering from chronic purulent inflamma- tion of bone which could not be successfully treated with surgery or antibiotics. After the use of PRP, bone union was achieved in all patients and there were no signs of inflammation. According to the authors' hypothesis, the effectiveness of this type of treatment results from platelet growth factor activity (particularly PDGF). Although the outcomes of PRP therapy in bone infection are very good, further research is necessary, especially with respect to the explanation of the mechanism of antibacterial effects of PRP.

\section{Summary}

Platelet-rich plasma therapy has been used in many fields of medicine, including orthopaedics and traumatology. The number of publications and reports evaluating the effectiveness of PRP therapy is constantly increasing. However, there are still few trials involving large treatment and control groups, and meta-analyses of the available data are difficult as the data are inhomogeneous. Further research should be conducted even if numerous separate studies show unsatisfactory results for particular disorders. Platelet-rich plasma preparations are not standardised; the treatment efficacy may be influenced by a number of factors which remain to be determined; new, more effective methods of treatment of many disorders are required due to the ever-increasing expectations of society; consequently, studies on PRP efficacy should continue and new indications should be established. The most important issue associated with PRP therapy is probably the preparation of international guidelines concerning the use of PRP in each indication and selection of the method of PRP preparation.

\section{Conflict of interest}

The authors declare no conflict of interest.

\section{References}

1. Marx RE. Platelet-rich plasma (PRP): what is PRP and what is not PRP? Implant Dentistry 2001; 10: 225-30.

2. Anitua E, Andia I, Ardanza B, Nurden P, Nurden AT. Autologous platelets as a source of proteins for healing and tissue regeneration. Thromb Haemost 2004; 91: 4-15.

3. Ferrari M, Zia S, Valbonesi M, Henriquet F, Venere G, Spagnolo S, Grasso MA, Panzani I. A new technique for hemodilution, preparation of autologous platelet-rich plasma and intraoperative blood salvage in cardiac surgery. Int J Artif Org 1987; 10: 47-50.

4. Marx RE, Carlson ER, Eichstaedt RM, Schimmele SR, Strauss JE, Georgeff KR. Platelet-rich plasma: growth factor enhancement for bone grafts. Oral Surg Oral Med Oral Pathol Oral Radiol Endod 1998; 85: 638-46.

5. Dutta SR, Singh P, Passi D, Patter P. Mandibular third molar extraction wound healing with and without platelet rich plasma: a comparative prospective study. J Maxillofac Oral Surg 2015; 14: 808-15.

6. Roselló-Camps À, Monje A, Lin GH, Khoshkam V, ChávezGatty M, Wang HL, Gargallo-Albiol J, Hernandez-Alfaro F. 
Platelet-rich plasma for periodontal regeneration in the treatment of intrabony defects: a meta-analysis on prospective clinical trials. Oral Surg Oral Med Oral Pathol Oral Radiol 2015; 120: 562-74.

7. Sclafani A, Azzi J. Platelet preparations for use in facial rejuvenation and wound healing: a critical review of current literature. Aesth Plast Surg 2015; 39: 495-505.

8. Dombek A, Korsak J, Paśnik K. Use of platelet growth factors in general surgery. Lek Wojsk 2013; 91: 350-4.

9. Kęsy L, Kopczyński P, Baszczuk A, Kopczyński Z. Methods of preparation of the platelet-rich plasma used in medicine as an accelerator of tissue regeneration. Pol Merkuriusz Lek 2014; 36: 283-6.

10. Eppley BL, Woodell JE, Higgins J. Platelet quantification and growth factor analysis from platelet-rich plasma: implications for wound healing. Plast Reconstr Surg 2004; 114: 1502-8.

11. Simpson AH, Milis L, Noble B. The role of growth factors and related agents in accelerating fracture healing. J Bone Joint Surg 2006; 88-B: 701-5.

12. Gautam VK, Verma S, Batra S, Bhatnagar N, Arora S. Platelet-rich plasma versus corticosteroid injection for recalcitrant lateral epicondylitis: clinical and ultrasonographic evaluation. J Orthop Surg 2015; 23: 1-5.

13. Behera P, Dhillon M, Aggarwal S, Marwaha N, Prakash M. Leukocyte-poor platelet-rich plasma versus bupivacaine for recalcitrant lateral epicondylar tendinopathy. J Orthop Surg 2015; 23: 6-10.

14. Kearney RS, Parsons R, Costa ML. Achilles tendinopathy management. A pilot randomized controlled trial comparing platelet-rich plasma injection with an eccentric loading programme. Bone Joint Res 2013; 2: 227-32.

15. de Vos RJ, Weir A, Tol JL, Verhaar JA, Weinans H, van Schie HT. No effects of PRP on ultrasonographic tendon structure and neovascularisation in chronic midportion Achilles tendinopathy. Br J Sports Med 2011; 45: 387-92.

16. Lis K. Evaluation of indicators of inflammation in the blood of patient in end stage of osteoarthritis. Studia Medyczne 2011; 21: 33-8.

17. Legwant Z, Gawęda J, Legwant-Wójcicka M, et al. Evaluation of comprehensive spa treatment of osteoarthritis of the knee at the "Włókniarz" Sanatorium in Busko-Zdrój. Studia Medyczne 2013; 29: 167-70.

18. Patel S, Dhillon MS, Aggarwal S, Marwaha N, Jain A. Treatment with platelet-rich plasma is more effective than placebo for knee osteoarthritis: a prospective, double-blind, randomized trial. Am J Sports Med 2013; 41: 356-64.

19. Angoorani H, Mazaherinezhad A, Marjomaki O, Younespour S. Treatment of knee osteoarthritis with plateletrich plasma in comparison with transcutaneous electrical nerve stimulation plus exercise: a randomized clinical trial. Med J Islam Repub Iran 2015; 29: 223.

20. Battaglia M, Guaraldi F, Vannini F, Rossi G, Timoncini A, Buda R, Giannini S. Efficacy of ultrasound-guided intra-articular injections of platelet-rich plasma versus hyaluronic acid for hip osteoarthritis. Orthopaedics 2013; 36: 1501-8.

21. Järvinen TA, Järvinen TL, Kääriäinen $M$, Kalimo $H$, Järvinen M. Muscle injuries: biology and treatment. Am J Sports Med 2005; 33: 745-64.

22. Wilczyński J, Bandyra A, Szaraniec K. The influence of kinesiotherapy on joint motion and process of strengthening selected muscules of leg after the episode of knee joint sprain. Studia Medyczne 2013; 29: 300-7.
23. Wojciechowska P. Physical activity and human health. Studia Medyczne 2014; 30: 254-60.

24. Quarteiro ML, Tognini JR, de Oliveira EL, Silveira I. The effect of platelet-rich plasma on the repair of muscle injuries in rats. Rev Bras Ortop 2015; 50: 586-95.

25. Jose Martinez-Zapata M, Orozco L, Balius R, Soler R, Bosch A, Rodas G, Til L, Peirau X, Urrutia G, Gich I, Bonfill X, Efficacy of autologous platelet-rich plasma for the treatment of muscle rupture with haematoma: a multicentre, randomised, double-blind, placebo-controlled clinical trial. Blood Transfus 2015; 10.2450: 99-115.

26. Reurink G, Goudswaard GJ, Moen MH, Weir A, Verhaar JA, Bierma-Zeinstra SM, Maas M, Tol JL; Dutch Hamstring Injection Therapy (HIT) Study Investigators. Platelet-rich plasma injections in acute muscle injury. $\mathrm{N}$ Engl J Med 2014; 370: 2546-7.

27. Hamid MS, Mohamed Ali MR, Yusof A, George J, Lee LP. Platelet-rich plasma injections for the treatment of hamstring injuries: a randomized controlled trial. Am J Sports Med 2014; 42: 2410-8.

28. Dhillon MS, Karna SK, Dhatt SS, Behera P, Bhatia A. Can platelet rich plasma stimulate human ACL growth in culture? A preliminary experience. Muscles Ligaments Tendons J 2015; 5: 156-61.

29. Komzák M, Hart R, Šmíd P, Puskeiler M, Jajtner P. The effect of platelet-rich plasma on graft healing in reconstruction of the anterior cruciate ligament of the knee joint: prospective study. Acta Chir Orthop Traumatol Cech 2015; 82: 135-9.

30. Silva A, Sampaio R. Anatomic ACL reconstruction: does the platelet-rich plasma accelerate tendon healing? Knee Surg Sports Traumatol Arthrosc 2009; 17: 676-82.

31. Radice F, Yánez R, Gutiérrez V, Resales J, Pinedo M, Coda S. Comparison of magnetic resonance imaging findings in anterior cruciate ligament grafts with and without autologous platelet-derived growth factors. Arthroscopy 2010; 26: 50-7.

32. Gołos J, Waliński T, Piekarczyk P, Kwiatkowski K. Results of the use of platelet-rich plasma in the treatment of delayed union of long bones. Ortop Traumatol Rehabil 2014; 16: 397-406.

33. Stanton T. High-concentrate PRP promotes healing in long-bone nonunions. AAOS Now; 2012.

34. Say F, Turkeli E, Bulbul M. Is platelet-rich plasma injection an effective choice in cases of delayed union or nonunion? Int J Care Injured 2013; 44: 37-46.

35. Bielecki TM, Gazdzik TS, Arendt J, Szczepanski T, Król W, Wielkoszynski T. Antibacterial effect of autologous platelet gel enriched with growth factors and other active substances. J Bone Joint Surg Br 2007; 89-B: 417-20.

36. Szypuła J, Kędziora J. The use of platelet rich plasma in treatment of chronic inflammation of bones. Pol Merkuriusz Lek 2009; 27: 132-5.

\section{Address for correspondence:}

\section{Andrzej Kotela}

Department of Orthopaedics and Traumatology

of Musculoskeletal System

$1^{\text {st }}$ Faculty of Medicine

Medical University of Warsaw

ul. Wołoska 137, 02-507 Warsaw, Poland

Phone: +48661166440

E-mail: andrzejkotela@op.pl 